\title{
The promiscuous estrogen receptor: evolution of physiological estrogens and response to phytochemicals and endocrine disruptors
}

\author{
Michael E. Baker ${ }^{\mathrm{a}, *}$, Richard Lathe $\mathrm{b}^{\mathrm{b}, *}$
}

${ }^{a}$ Division of Nephrology-Hypertension, Department of Medicine, 0693, University of California, San Diego, 9500 Gilman Drive, La Jolla, California 92093-0693

${ }^{\mathrm{b}}$ Division of Infection and Pathway Medicine, University of Edinburgh, Little France, Edinburgh

*Corresponding authors

E-mail addresses: mbaker@ucsd.edu (M. Baker), richardlathe@ed.ac.uk (R. Lathe).

\begin{abstract}
Many actions of estradiol (E2), the principal physiological estrogen in vertebrates, are mediated by estrogen receptor- $\alpha(E R \alpha)$ and ER $\beta$. An important physiological feature of vertebrate ERs is their promiscuous response to several physiological steroids, including estradiol (E2), $\Delta^{5}$-androstenediol, $5 \alpha$-androstanediol, and 27-hydroxycholesterol. A novel structural characteristic of $\Delta^{5}$-androstenediol, $5 \alpha$-androstanediol, and 27-hydroxycholesterol is the presence of a C19 methyl group, which precludes the presence of an aromatic A ring with a $\mathrm{C} 3$ phenolic group that is a defining property of E2. The structural diversity of these estrogens can explain the response of the ER to synthetic chemicals such as bisphenol A and DDT, which disrupt estrogen physiology in vertebrates, and the estrogenic activity of a variety of plant-derived chemicals such as genistein, coumestrol, and resveratrol. Diversity in the A ring of physiological estrogens also expands potential structures of industrial chemicals that can act as endocrine disruptors. Compared to E2, synthesis of 27-hydroxycholesterol and $\Delta^{5}$-androstenediol is simpler, leading us, based on parsimony, to propose that one or both of these steroids or a related metabolite was a physiological estrogen early in the evolution of the ER, with E2 assuming this role later as the canonical estrogen. In addition to the well-studied role of the ER in reproductive physiology, the ER also is an important transcription factor in non-reproductive tissues such as the cardiovascular system, kidney, bone, and brain. Some of these ER actions in non-reproductive tissues appeared early in vertebrate evolution, long before mammals evolved.
\end{abstract}




\section{Introduction}

\subsection{Promiscuity in steroids that activate the estrogen receptor}

As our understanding of ligand-protein interactions has expanded, appreciation for the role of promiscuity as a force in evolution has increased [1-5]. The term 'promiscuity' is akin to that of 'biological messiness' [6]. We use promiscuity here as the capacity of the estrogen receptor (ER) to bind physiological steroids with diverse structures. In particular, the A ring of estradiol (E2), the main physiological estrogen, differs from the A ring in $\Delta^{5}$-androstenediol, $5 \alpha$-androstanediol, and 27-hydroxycholesterol (Figure 1), as well as from the A ring of other classes of vertebrate adrenal and sex steroids (Figure 2). Indeed, the aromatic A ring and C3 phenolic group, characteristic of E2, have been exploited to synthesize 'synthetic estrogens' that are used to treat estrogen-dependent diseases (Figure 3) [7, 8].
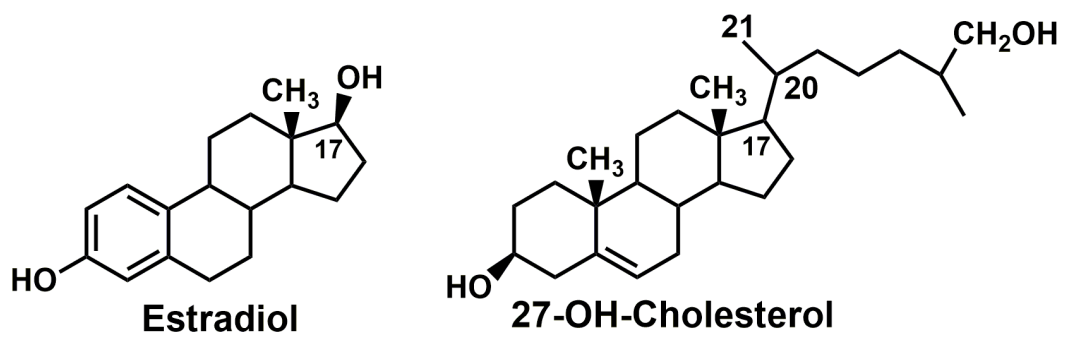<smiles>C[C@]12CCC3C(CCC4C3CCC3[C@H](O)[C@H](O)CC[C@]43C)C1CC[C@H]2O</smiles>

$\Delta^{5}$-Androstenediol
$5 \alpha$-Androstanediol<smiles>[Z1]C(CCCC(C)C)C1CCC2C3CCc4cc(O)ccc4C3CCC12C</smiles>

Paraestrol A

Figure 1. Promiscuity in ligands that are transcriptional activators of the estrogen receptor. The estrogen receptor is activated by steroids with diverse structures $[8,42,44,76]$. Estradiol, the main physiological estrogen, contains an aromatic A ring with a C3-hydroxyl. By contrast, $\Delta^{5}$-androstenediol, $5 \alpha$-androstanediol, and 27-hydroxycholesterol contain a cyclohexane $\mathrm{A}$ ring, with a $3 \beta$-hydroxyl and a C19 methyl group. $\Delta^{5}$-Androstenediol and 27-hydroxycholesterol contain a B ring with an unsaturated bond between C5 and C6. $\Delta^{5}$-Androstenediol, $5 \alpha$-androstanediol, and 27-hydroxycholesterol are physiological estrogens $[27,46,50,61,67,80]$. Paraestrol A, a cholesterol analog with an aromatic A ring and a C3 phenolic group, has been proposed to be one of a class of cholesterol derivatives that may have been transcriptional activators of the ancestral estrogen receptor [15]. 


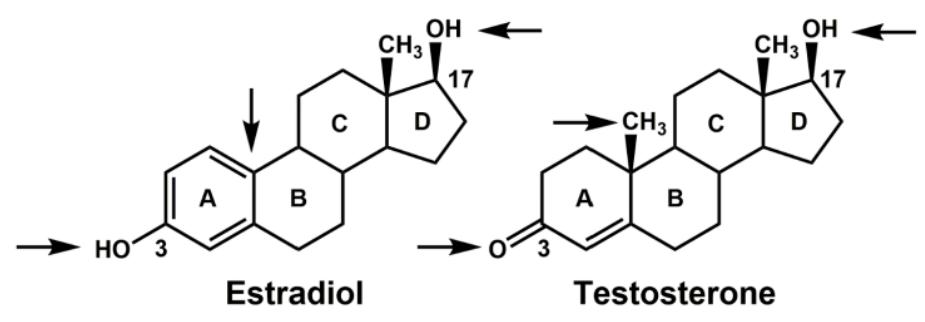

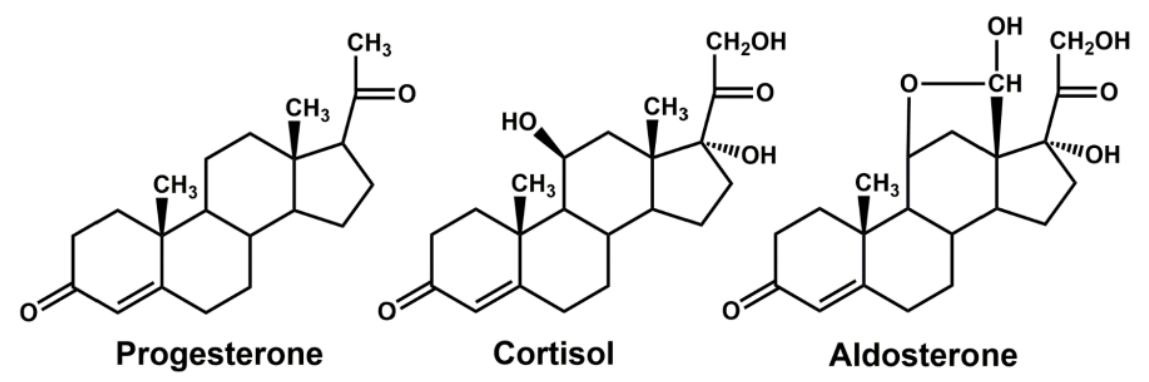

Figure 2. Comparison of estradiol with other sex steroids and adrenal steroids.

Testosterone, progesterone, cortisol, and aldosterone contain an A ring with an unsaturated bond between C4 and C5, a C3 ketone, and a C19 methyl group. Estradiol has an aromatic A ring with a C3 hydroxyl and lacks a C19 methyl group. The absence of a C19 methyl group in estradiol allows a close fit between the A ring on estradiol and ER $\alpha$ and ER $\beta$, as seen in the crystal structures of human $\operatorname{ER} \alpha[34,36]$ and $\operatorname{ER} \beta[35,113]$.<smiles>CC/C(=C(\CC)c1ccc(O)cc1)c1ccc(O)cc1</smiles><smiles>CC/C(=C(\c1ccccc1)c1ccc(OCCN(C)C)cc1)c1ccccc1/C(=C(\CC)c1ccc(OCCN(C)C)cc1)c1ccc(OCCN(C)C)cc1</smiles>

Figure 3. Synthetic estrogens. The role of an aromatic A ring with a C3-alcohol in the biological activity of estradiol provided a template for the synthesis of drugs to regulate estrogen action, such as diethylstilbestrol and 4-hydroxytamoxifen. Diethylstilbestrol is a high-affinity agonist for both $\mathrm{ER} \alpha$ and ER $\beta$ [27], 4-hydroxytamoxifen is an important anti-estrogen, while tamoxifen, which lacks a phenolic A ring is inactive [27, 42]. 
Unfortunately, various industrial chemicals containing phenolic groups can disrupt physiological responses to the ER in healthy people, and thus act as endocrine disruptors (Figure 4) [8-12].

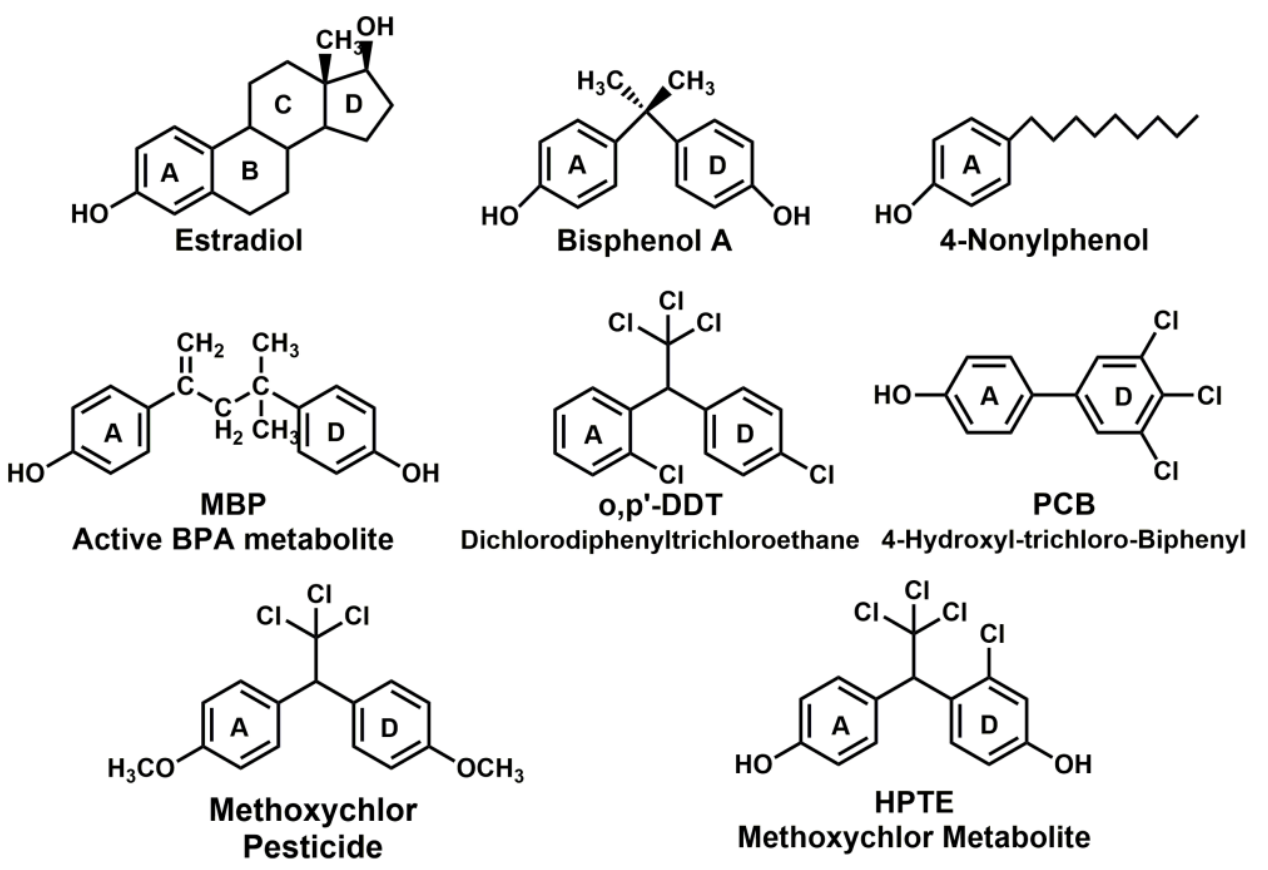

Figure 4. Synthetic chemicals that act as endocrine disruptors. Many synthetic chemicals used in plastics and other industrial products contain a phenolic group that mimic the A ring of estradiol or two phenolic groups that mimic the A and D rings of estradiol $[40,77]$. For example, bisphenol A, which is used in plastics and is widespread in the environment, is a xeno-estrogen [40, 41, 114]. BPA can be metabolized to 4-methyl-2,4-bis(4-hydroxyphenyl)pent-1-ene (MBP), which has transcriptional activity at $\mathrm{nM}$ concentrations $[115,116]$. Metabolism of the pesticide methoxychlor [1,1,1-trichloro-2,2-bis(4-methoxyphenyl)ethane] to HPTE (2,2-bis( $p$-hydroxyphenyl)-1,1,1-trichloroethane) also yields an active xeno-estrogen that is approximately 100 -fold more active than methoxychlor [75]. Interestingly, despite the absence of a phenolic group, o,p'-DDT (2,2-bis(o,p-dichlorophenyl)-1,1,1-trichloroethane) is a pesticide with estrogenic activity $[76,77]$.

Interestingly, many natural products in plants also contain phenolic structures, which yield phytochemicals that are transcriptional activators of the ER (Figure 5) [8, 9, 13]. 


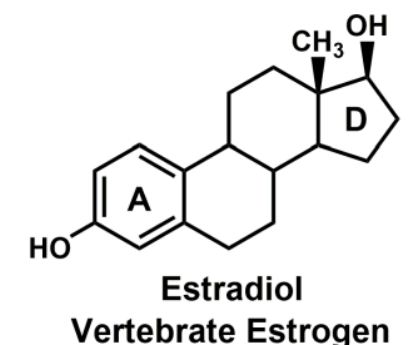

Vertebrate Estrogen<smiles>O=c1c(-c2ccc(O)cc2)coc2cc(O)cc(O)c12</smiles>

Soy Estrogen<smiles>Oc1ccc(/C=C/c2cc(O)cc(O)c2)cc1</smiles>

Resveratrol Non-Steroidal Estrogen Grape Skin Estrogen

\section{Figure 5. Chemicals from plants that act as estrogens.}

Many chemicals in plants contain one or two 6-carbon rings with hydroxyl substituents that can mimic estradiol such that the phytochemical is an agonist for ER $\alpha$ and $\operatorname{ER} \beta[8,40,42,43]$. Genistein [43] and coumestrol [77] contain aromatic structures that can mimic the A and D rings of estradiol. Resveratrol is a phytoestrogen found in the skins of red grapes [13].

The diversity in the A ring of physiological estrogens (Figure 1) also expands the potential structures of chemicals that can be used as drugs for treating estrogen-dependent diseases in vertebrates, as well as of industrial chemicals that need to be screened for potential disruption of estrogen physiology $[9,14]$.

Synthesis of 27-hydroxycholesterol and $\Delta^{5}$-androstenediol is simpler than that of E2 [4, 9, 15] (Figure 6), and this has important implications for the identity of the estrogen that was the transcriptional activator the ancestral ER [9, 16-18]. 

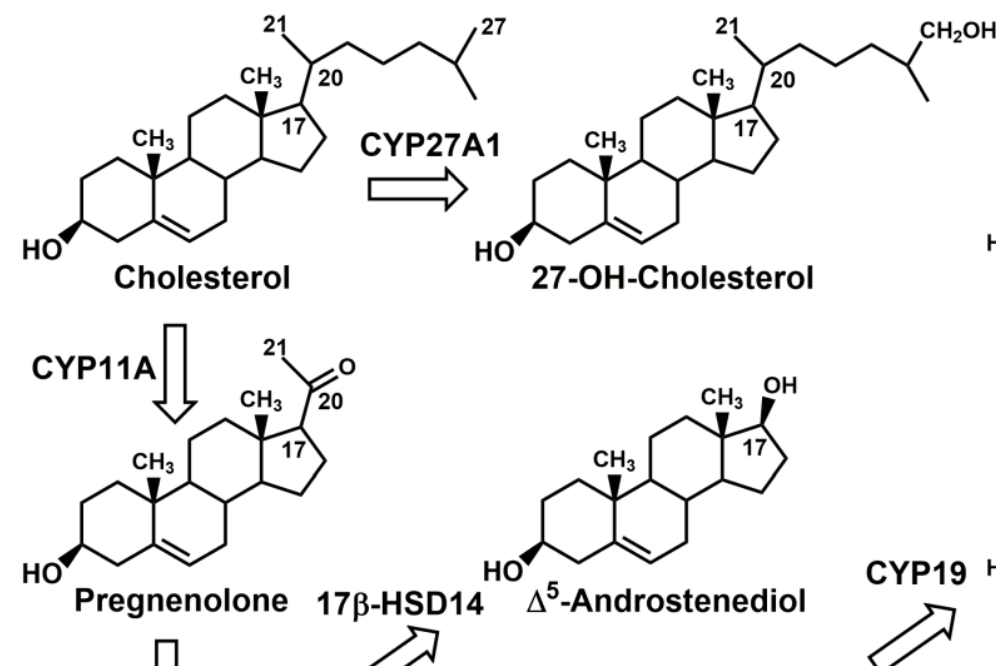<smiles>CCCCCC1CCC2C(CC[C@@]3(C)C2CC[C@H]3O)c2ccc(O)cc21</smiles>

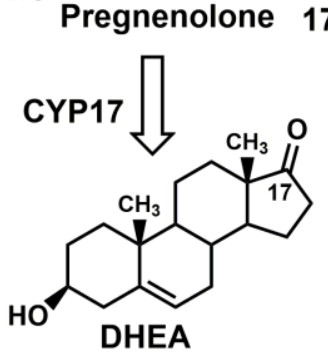

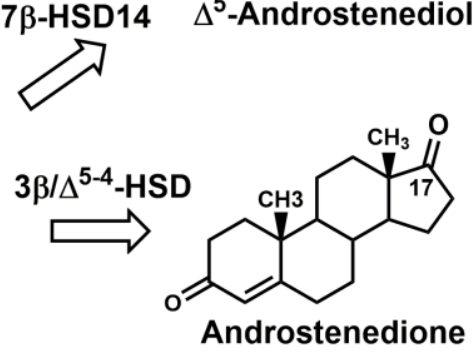

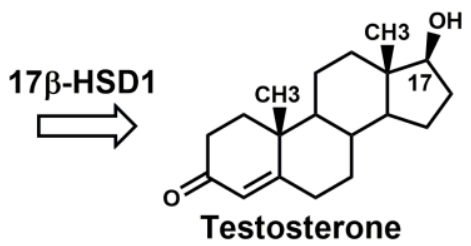

Figure 6. Comparison of pathway for synthesis of estradiol, $\Delta^{\mathbf{5}}$-androstenediol, and 27-hydroxycholesterol. E2 is synthesized in three enzymatic steps from dehydroepiandrosterone (DHEA) $[4,80]$. By contrast, $\Delta^{5}$-androstenediol is synthesized from DHEA in one step $[46,53]$. 27-Hydroxycholesterol is synthesized in one step from cholesterol.

The earliest ortholog of mammalian ER is found in amphioxus [4, 15, 19-21], a marine chordate that diverged from vertebrates more than 520 million years ago. Based on parsimony, we propose that one or both of these $\mathrm{C} 19$-containing steroids or a related metabolite were ligands for the early chordate ER, with E2 evolving later as the canonical estrogen $[9,16]$. Many actions of the ER in non-reproductive tissues evolved in vertebrates long before the evolution of mammals, in which reproductive activity of the ER has long been a main focus [22, 23]. An evolutionary perspective of ER signaling $[9,24]$ provides insights into its promiscuous actions in different tissues: brain, heart, bone, and kidney, as well as traditional ER activities in reproductive organs.

\section{Estradiol, a hormone with many physiological actions in females and males}

Owing to its key role in female reproduction, E2 often is described as a 'female' sex hormone. However, E2 also is an important steroid in males [25, 26]. The physiological actions of E2 and other estrogens are mediated by two ER isoforms, ER $\alpha$ and ER $\beta$ [27-29]. Through transcriptional activation of these ERs, estrogens regulate variety physiological responses in reproductive organs [22, 23, 26, 28], brain [30-33], bone, and the cardiovascular system [22]. 


\section{What is an estrogen?}

E2 is the major physiological ligand for the vertebrate ERs [23, 28]. Compared to other adrenal and sex steroids, E2 is a compact hydrophobic molecule with few side chains that could interact with the ER (Figure 2). The aromatic A ring on E2 is unique among adrenal and sex steroids (Figure 2). The crystal structures of ER $\alpha$ and ER $\beta$ provide insights into the key contacts between E2 and the ER $[8,34,35]$. Owing to the aromatic chemistry in the A ring, the C3-alcohol can function as a hydrogen-bond donor and acceptor with Arg-394 and Glu-353 in human ER $\alpha$ [8, 34] (Figure 7) and with Arg-346 and Glu-305 in ER $\beta$ [35]. In addition, because of the aromatic A ring, the interface between the A and B ring is flat and E2 lacks a C19 methyl group, which allows $\mathrm{ER} \alpha$ and ER $\beta$ to form a close contact with this part of E2 (Figure 7) [8, 14, 34, 35]. By contrast, testosterone and other 3-ketosteroids (Figure 2) have a different A ring and contain a C19 methyl group, and thus their receptors use a different chemistry to contact the A ring [36-38].

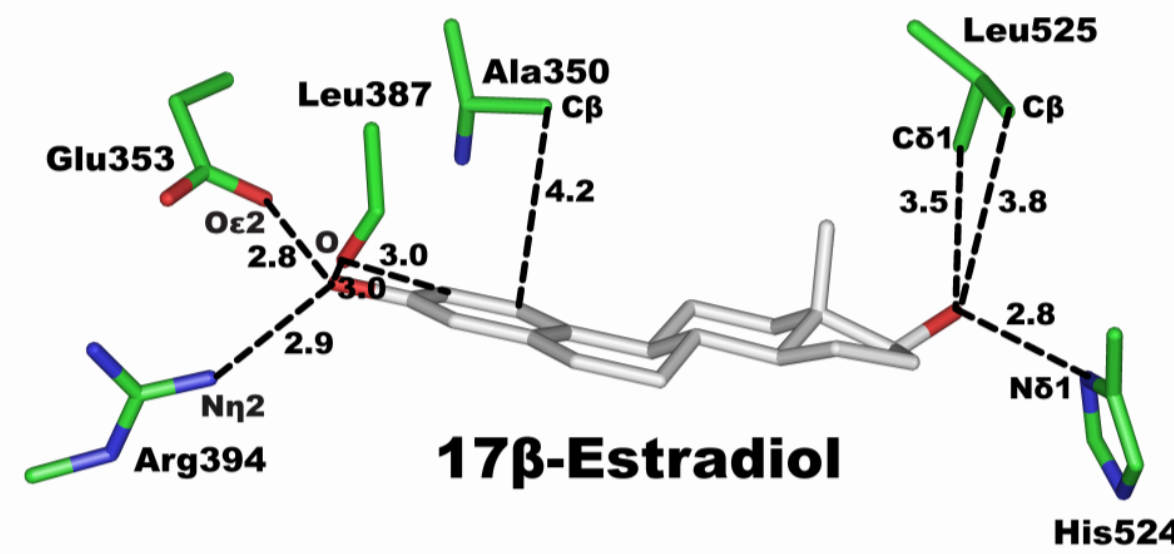

Figure 7. Structure of ER $\alpha$ with 17 $\beta$-estradiol [34, 117].

ER $\alpha$ (PDB: 1G50) [117] was used for this figure. The C3-hydroxyl on E2 forms hydrogen bonds with Glu-353 and Arg-394 on ER $\alpha$. The 17ß-hydroxyl has a hydrogen bond with His-524.

Also important in binding of E2 to the ER is the hydroxyl on the D ring, which has a stabilizing contact with His-524 in ER $\alpha$ (Figure 7) and with His-475 in ER $\beta$ [8, 9, 34, 35].

The spatial relationship of the functional groups on the A and D rings on E2 has been used to develop chemicals containing properly spaced A and D rings that are either estrogens, such as diethylstilbestrol (DES) or anti-estrogens such as 4-OH-tamoxifen (4-OH-TAM) and raloxifene [7, 8, 34, 36, 39] (Figure 3).

Many synthetic chemicals in the environment contain a phenolic group corresponding to the A ring on $\mathrm{E} 2$ and often contain a D ring with some similarity to the D ring on E2, which together promotes binding to the ER, disrupting normal estrogen physiology (Figure 4) [10, 11, 40]. For 
example, the phenolic hydroxyls on bisphenol A (BPA) contact Arg-394 and Glu-353 and His-524 in human ER $\alpha$ (Figure 8) [14, 41].

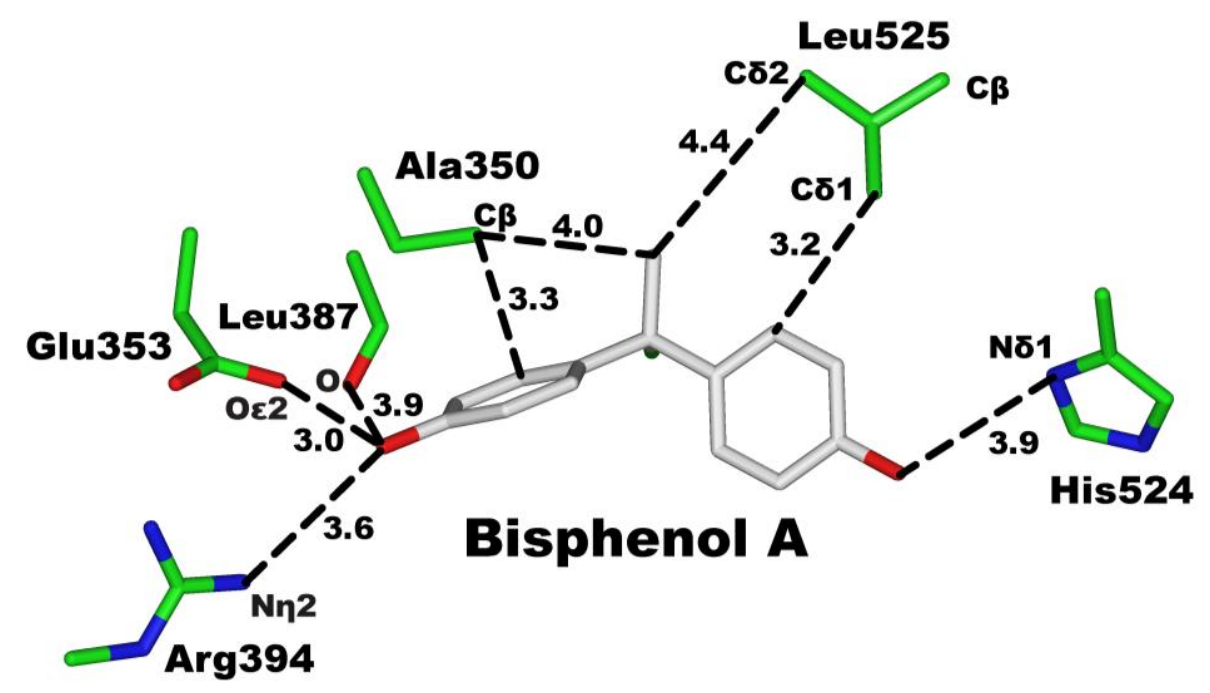

Figure 8. Structure of ER $\alpha$ with bisphenol A.

$\mathrm{ER} \alpha$ (PDB: 3UU7) [41] was used for this figure. The A ring on BPA forms hydrogen bonds with Glu-353 and Arg-394 in ER $\alpha$. The hydroxyl on the second ring forms a hydrogen bond with His-524.

Similarly, many chemicals in plants contain an aromatic A ring corresponding to the A ring and a second 6-carbon ring that can mimic the D ring on E2 (Figure 5), which promotes binding with $\mathrm{nM} \mathrm{K}_{\mathrm{d}}$ and transcriptional activation of $\operatorname{ER} \alpha$ and $\operatorname{ER} \beta[11,40,42]$. For example, genistein (Figure 9) [43] and E2 (Figure 7) have similar contacts between their A rings and Arg-394 and Glu-353 in human ER $\alpha$, and Arg-346 and Glu-305 in ER $\beta$, as well as their D rings and His-524 in $\mathrm{ER} \alpha$, and His-475 in ER $\beta[14,43]$.

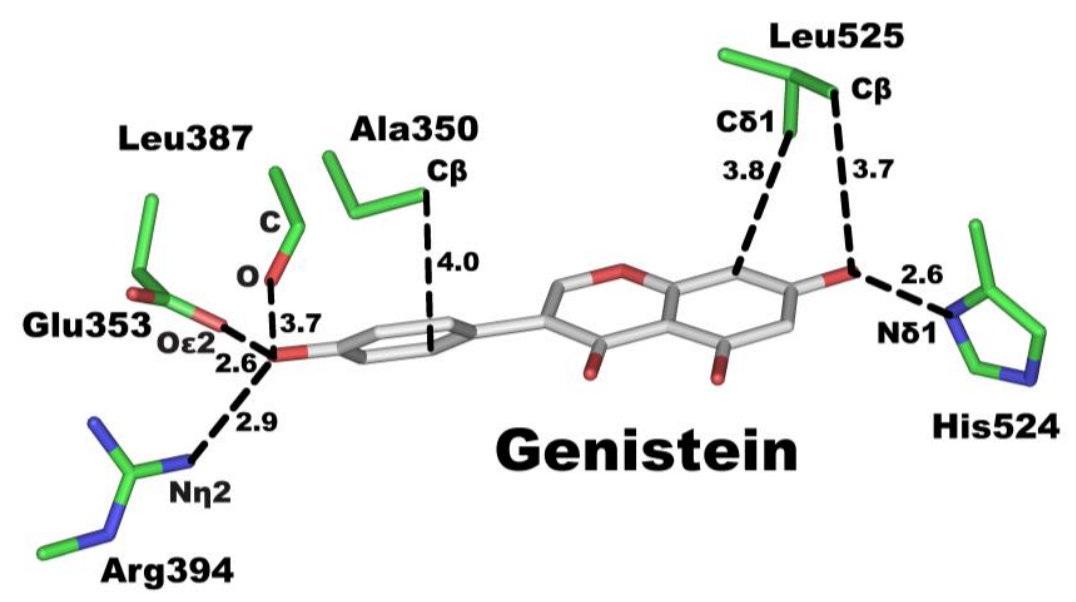

Figure 9. Structure of $\mathbf{E R} \alpha$ with genistein. $\quad \mathrm{ER} \alpha$ (PDB: 1X7R) [43] was used for this figure. The A ring on genistein forms hydrogen bonds with Glu-353 and Arg-394 in ERo. The hydroxyl group on the D ring on genistein forms a hydrogen bond with His-524. 


\section{Activities of estrogens with novel structures}

In the past decade the concept that a steroid must have an aromatic A ring with a C3-phenolic group to be a physiological estrogen has undergone revision because steroids with a different A ring have been shown to be transcriptional activators of ER $\alpha$ and ER $\beta$, and thus act as physiological estrogens [30, 44-47]. $\quad \Delta^{5}$-Androstenediol, $5 \alpha$-androstanediol, and 27-hydroxycholesterol (Figure 1) are examples of physiological estrogens that do not contain an aromatic A ring with a $\mathrm{C} 3$ phenolic group, and thus expand the potential structures of physiological ligands for the ER. Phytochemicals and synthetic industrial chemicals also have structures that differ from that of E2. Below we briefly review some physiological activities of these estrogens with novel structures.

\section{1 $\Delta^{5}$-Androstenediol}

$\Delta^{5}$-Androstenediol (Figure 1) competes with E2 for binding to the ER in rat uterus cytosol $[48,49]$ and has estrogenic activity in MCF-7 cells [50]. Competitive analysis of binding of $\Delta^{5}$-androstenediol to purified human $\mathrm{ER} \alpha$ and rat $\mathrm{ER} \beta$ found that $\Delta^{5}$-androstenediol had a $\mathrm{K}_{\mathrm{i}}$ of 3.6 $\mathrm{nM}$ and $0.9 \mathrm{nM}$, respectively, for human $\mathrm{ER} \alpha$ and rat $\mathrm{ER} \beta$ [27].

$\Delta^{5}$-Androstenediol binding to ER $\beta$ in astrocytes and microglia inhibits activation of inflammatory response genes [46, 51]. $\Delta^{5}$-Androstenediol is synthesized in brain microglia [52, 53]. Inhibition of inflammation in microglia is important in a variety of neurodegenerative diseases [54, 55], including multiple sclerosis, Parkinson's disease, and amyotrophic lateral sclerosis [56-58]. Interestingly, E2 is not a potent repressor of inflammation in microglia, and $5 \alpha$-androstanediol has weak activity $[46,51]$; that is, $\Delta^{5}$-androstenediol has a physiological activity that is absent in E2. Thus, displacement by E2 of $\Delta^{5}$-androstenediol from ER $\beta$ counteracts the inhibitory effect of $\Delta^{5}$-androstenediol on inflammation. This counteracting effect of E2 on $\Delta^{5}$-androstenediol inhibition of inflammation in the brain microglia may explain higher incidence of multiple sclerosis in women $[51,59,60]$. Interestingly, binding by the phytoestrogen coumestrol to ER $\beta$ (Figure 5) also inhibits inflammation in microglia. However, the phytoestrogen genistein has no effect [46].

\subsection{5a-Androstanediol}

Analysis of binding of $5 \alpha$-androstanediol to purified human $\operatorname{ER} \alpha$ and rat $\operatorname{ER} \beta$ found that $5 \alpha$-androstanediol had $\mathrm{K}_{\mathrm{i}}$ values of $6 \mathrm{nM}$ and $2 \mathrm{nM}$, respectively, for human ER $\alpha$ and rat ER $\beta$ [27]. $5 \alpha$-Androstanediol binding to ER $\beta$ has a role in controlling prostate growth $[30,61,62]$ and inflammation in the brain [31,63]. Indeed, $5 \alpha$-androstanediol may be a second physiological estrogen in the brain $[30,31,63]$. 
Owing to the decline in E2 synthesis after menopause, circulating $\Delta^{5}$-androstenediol [64-66] may be important physiological estrogens in post-menopausal women.

\subsection{7-Hydroxycholesterol}

27-Hydroxycholesterol appears to be a transcriptional regulator of both ER $\alpha$ and ER $\beta$ [47, 67-69]. 27-Hydroxycholesterol binding to ER $\alpha$ reduces bone density [69, 70]. The $\mathrm{K}_{\mathrm{d}}$ values of 27-hydroxycholesterol for $\mathrm{ER} \alpha$ and $\mathrm{ER} \beta$ are about $1.3 \mu \mathrm{M}$ and $0.4 \mu \mathrm{M}$, respectively $[47,67,68]$, which are over $10^{3}$-fold higher than the $\mathrm{K}_{\mathrm{d}}$ of E2 for human ER $\alpha$ and ER $\beta$ [27]. Levels of circulating 27-hydroxycholesterol are in the range 0.15 to $0.73 \mu \mathrm{M}[47,67,71]$.

27-Hydroxycholesterol acts through activation of ER $\alpha$ to promote the growth of

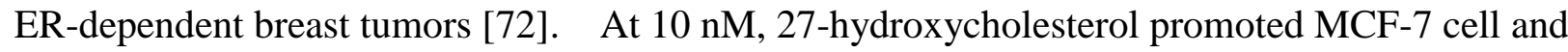
Ishikawa cell proliferation [73].

\subsection{Paraestrol A}

Paraestrol A is a recently described steroid that resembles cholesterol and with an aromatic A ring (Figure 1). Paraestrol A has been proposed to be an ancestral estrogen [15]. Although this steroid has not been found in mammals, clearly paraestrol A or a metabolite, such as 27-OH-paraestrol A, must be considered as a possible 'first' transcription activator of the ER in amphioxus or another chordate in which the first steroid-activated ER evolved [9, 15, 19, 74].

\subsection{Phytochemicals}

Many plants synthesize chemicals that have sufficient structural similarity to E2 so as to bind $E R \alpha$ and $E R \beta[8,13,14,42]$ (Figure 5). These chemicals have an A ring with an alcohol at C3 and a 6-carbon D ring. Despite the different D ring structures in genistein (6-carbon ring) and E2 (5-carbon ring), the alcohol on the genistein D ring conserves a key contact with $\mathrm{N} \delta 1$ on His524 in ER $\alpha$ (Figure 9). The role of these phytoestrogens in plants is not fully understood, although protection against herbivores through phytoestrogen interference in herbivore physiology is one possibility. There is increased interest in the use of these phytoestrogens in human health [13]; however, their benefits remain controversial.

\subsection{Environmental chemicals and endocrine disruptors}

A major concern regarding the health of the environment is that many synthetic chemicals have structures that allow binding to $\operatorname{ER} \alpha$ and $\operatorname{ER} \beta[8,9,14,42]$ (Figure 4). For example, bisphenol A (BPA) and E2 conserve key binding interactions with ER $\alpha$ (Figure 8). Metabolism of 
pesticide methoxychlor to HPTE results in an xenoestrogen with approximately 100 -fold more activity demonstrating the importance of the phenolic group [75]. Unexpectedly, DDT (dichlorodiphenyltrichloroethane), which lacks alcohol substituents, is nevertheless a xenoestrogen $[76,77]$

\section{An evolutionary perspective. What is the ancestral estrogen and what were its ancestral physiological activities; that is, why is $\mathbf{E 2}$ more than a reproductive hormone?}

The traditional model is that E2 and its metabolites are the main physiological estrogens in mammals, and thus the estrogenic actions of $\Delta^{5}$-androstenediol, $5 \alpha$-androstanediol, and 27-hydroxycholesterol which lack an aromatic A ring are perplexing. The physiological actions of $\mathrm{ER} \alpha$ and ER $\beta$ in non-reproductive tissues, such as the brain, also deserve elucidation. To begin to provide a perspective on these phenomena, we draw on Dobzhansky [78] with a modified paradigm 'Nothing in estrogen physiology makes sense except in the light of evolution'. We use this evolutionary perspective $[9,79,80]$ to investigate various inter-related questions including when did the ER arise, what were the ligand(s) that activate the ancestral ER receptor, and what were the physiological actions of the ER in basal chordates and vertebrates?

\subsection{When did the ER arise?}

Nuclear receptors are found in basal animals, but not in plants, yeast, or bacteria [81-86]. Receptors for adrenal and sex steroids evolved in deuterostomes [18, 81, 82, 85-88]. Sequence analysis indicates that the ER evolved before the AR, GR, MR, and PR [4, 18, 74, 87].

Amphioxus, a protochordate in the line leading to vertebrates, contains an ancestral ER and another steroid receptor (SR), which appears to be the ancestor of the 3-ketosteroid receptors [19-21, 89]. Interestingly, E2 does not bind to amphioxus ER. However, E2 is a transcriptional activator of the SR, which is not activated by androgens, glucocorticoids, mineralocorticoids, or progestins [19-21].

\subsection{What was the ancestral estrogen?}

Thus far, only E2 and E1 have been found to be transcriptional activators of amphioxus SR $[19,20]$. Other potential estrogens such as $\Delta^{5}$-androstenediol, $5 \alpha$-androstanediol, 27-hydroxycholesterol, and paraestrol A have not been tested for activation of amphioxus SR. The synthesis of these steroids is more parsimonious than the pathway for the synthesis of E2 (Figure 6). In fact, synthesis of testosterone is simpler than that of E2. Indeed, testosterone is an intermediate in the synthesis of E2, suggesting that the AR should have evolved before the ER.

Two hypotheses have been advanced to explain the puzzle that E2 is an ancestral ligand for the SR despite the more complex synthesis of E2 relative to testosterone. Both hypotheses rely on 
the identity of the ancestral estrogen. In one hypothesis, based on E2 being the ancestral estrogen, Thornton [17-19] proposed the novel 'ligand exploitation' model in which E2 was the ancestral ligand for the first ER, and testosterone was inactive because the AR had not yet evolved [19]. Through gene duplication and sequence divergence of an ancestral SR, receptors for the AR and other 3-ketosteroid receptors evolved. In this model, the evolution of the AR 'exploited' the presence of testosterone as a biological intermediate in estrogen synthesis [17-19]. Further gene duplications led to the evolution of the other adrenal and sex steroid receptors.

A more conventional model uses parsimony in the pathway for synthesis of estrogens is to identify the ancestral estrogen(s) $[9,16]$. The ancestral estrogen is proposed to be $\Delta^{5}$-androstenediol, which is synthesized in one step from dehydroepiandrosterone (DHEA) (Figure 6) $[9,16]$. Synthesis of $\Delta^{5}$-androstenediol does not require either aromatase or $3 \beta, \Delta^{4-5}$-hydroxysteroid dehydrogenase, providing a more parsimonious synthesis than for either E2 or E1, which requires both enzymes.

The evidence that $\Delta^{5}$-androstenediol is a high-affinity ligand for the ER supports considering this steroid as a ligand for the ancestral ER. 5 $\alpha$-Androstanediol, 27-hydroxycholesterol, and paraestrol A also may be ligands for the ancestral ER. Of the three steroids with a C19 methyl group, the synthesis of 27-hydroxycholesterol from cholesterol is the most parsimonious [9] (Figure 6). The recent report by Markov et al. [15] of paraestrol A, an aromatized cholesterol derivative, provides another potential ancestral ligand for the ER.

\section{6. $E R \alpha$ and $E R \beta$ are expression in the brain: transcriptional activation by $5 \alpha$-androstanediol and $\Delta 5$-androstenediol}

The presence of an ER and SR in ovaries and testis in amphioxus indicates that some reproductive functions of estrogens in males and females evolved in a basal chordate $[19,20,90]$, although transcriptional activation of the ER in uterus or prostate evolved hundreds of millions of years after the evolution of amphioxus, lamprey, and coelacanth. As mentioned above, the ER has physiological actions in the brain. $\operatorname{ER} \alpha$ and $\operatorname{ER} \beta$ are reported to be expressed in different regions in the brain during development in males and females [28, 30, 91-94]. Thus, E2 is a neurosteroid, as well as a reproductive steroid. Moreover, $\Delta^{5}$-androstenediol and $5 \alpha$-androstanediol, which have a different A ring than E2, have been found to be transcriptional activators of the brain ER [30, 46].

The estrogenic activity of steroids with a C19 methyl group may provide a selective advantage in estrogen physiology that is not provided by E2. In this regard, $5 \alpha$-androstanediol has been proposed to be a second physiological estrogen in fetal mouse brain based on the timing of ER $\beta$ synthesis in mouse brain, which begins at embryonic day 10.5 [30, 95, 96], well before embryonic day 18.5 when aromatase (which catalyzes the synthesis of E2) is first expressed. Thus, 
there are at least two physiological estrogens in mouse brain. Moreover, other studies find that ER $\beta$ mediates the actions of $5 \alpha$-androstanediol in human brain cells [31, 63].

In addition, $\Delta^{5}$-androstenediol is synthesized in the brain $[52,53]$, providing a third endogenous estrogen in mouse brain. Finally, 27-hydroxycholesterol also is present in the brain [97]. Thus, there may be four physiological neuro-estrogens. The unique anti-inflammatory response in brain microglia due to binding of $\Delta^{5}$-androstenediol to $\operatorname{ER} \beta$ may be the first of a series of specialized physiological activities for $\Delta^{5}$-androstenediol, $5 \alpha$-androstanediol, and 27-hydroxycholesterol in the brain and other organs. It is interesting that E2 and $\Delta^{5}$-androstenediol regulate different physiological responses through ER $\beta$ in microglia.

We propose that some activities of the ER in different regions of the mammalian brain [30, $32,33,98]$ were important in amphioxus or in lamprey. Although the head and brain are poorly developed in amphioxus [99-102], many genes in amphioxus are expressed in the brain in lamprey and other vertebrates $[100,102,103]$. It appears that these genes were important in the evolution of the brain during the transition from amphioxus to lamprey [100-102]. It is tempting to speculate that transcriptional regulation of the SR in an ancestral amphioxus by $\Delta^{5}$-androstenediol, $5 \alpha$-androstanediol, 27-hydroxycholesterol, or paraestrol A, as well as by E2, was important in brain evolution $[79,80]$, which would place the origins of responses to estrogens in the brain as contemporary with its reproductive actions.

Also relevant for the evolution of estrogen physiology is the presence in lamprey of a PR and corticoid receptor (CR) [4, 18, 104], which is the ancestor of the GR and MR [4, 104]. These steroid receptors have transcriptional properties that similar to their mammalian orthologs [38, 105]. Crosstalk between the ER and the PR, GR, and MR may have contributed to the evolution of the brain [106-108] and other organs during the transition from amphioxus to lamprey.

\section{Future research}

There is a need to verify the presence of $\Delta^{5}$-androstenediol, $5 \alpha$-androstanediol, and 27-hydroxycholesterol in amphioxus and lamprey to provide evidence for the physiological activity of these 3-ketoestrogens early in the evolution of the ER. Synthesis of $\Delta^{5}$-androstenediol, $5 \alpha$-androstanediol, and 27-hydroxycholesterol in amphioxus and lamprey can be studied through metabolism of radioactive cholesterol in tissue extracts from amphioxus and lamprey. Of course, transcriptional activation of amphioxus SR and lamprey ER by $\Delta^{5}$-androstenediol, $5 \alpha$-androstanediol, and 27-hydroxycholesterol will be necessary to determine their biological activity in relation to E2. The functions of 3-keto-estrogens in mammals merit further study in view of the evidence that $5 \alpha$-androstanediol and $\Delta^{5}$-androstenediol are important in prostate [61] and brain microglia [46, 51], respectively. Investigation of $\Delta^{5}$-androstenediol, $5 \alpha$-androstanediol, 
and 27-hydroxycholesterol actions in tissues with ER $\alpha$ and $\operatorname{ER} \beta$ during different stages in development may uncover additional physiological responses mediated by these 'alternative' estrogens. In this regard, the slow continuous increase in DHEA synthesis from birth, which is coupled with increased synthesis of $\Delta^{5}$-androstenediol [109], merits further study, as does the role of $\Delta^{5}$-androstenediol during fetal development [110], when DHEA levels are high [111, 112].

\section{Author contributions}

M.E.B and R.L. wrote and edited the MS.

\section{Funding}

M.E.B. was supported by Research Fund \#3096.

\section{Competing interests}

We have no competing interests.

\section{References}

[1] G.N. Eick, J.K. Colucci, M.J. Harms, E.A. Ortlund, J.W. Thornton, Evolution of minimal specificity and promiscuity in steroid hormone receptors, PLoS genetics, 8 (2012) e1003072.

[2] R. Lathe, Steroid and sterol 7-hydroxylation: ancient pathways, Steroids, 67 (2002) 967-977.

[3] R. Lathe, Y. Kotelevtsev, Steroid signaling: ligand-binding promiscuity, molecular symmetry, and the need for gating, Steroids, 82 (2014) 14-22.

[4] M.E. Baker, D.R. Nelson, R.A. Studer, Origin of the response to adrenal and sex steroids: Roles of promiscuity and co-evolution of enzymes and steroid receptors, J Steroid Biochem Mol Biol, 151 (2015) 12-24.

[5] W.M. Atkins, Biological messiness vs. biological genius: Mechanistic aspects and roles of protein promiscuity, J Steroid Biochem Mol Biol, (2014).

[6] D.S. Tawfik, Messy biology and the origins of evolutionary innovations, Nat Chem Biol, 6 (2010) 692-696.

[7] B.S. Katzenellenbogen, J.A. Katzenellenbogen, Biomedicine. Defining the "S" in SERMs, Science, 295 (2002) 2380-2381.

[8] J.A. Katzenellenbogen, The 2010 Philip S. Portoghese Medicinal Chemistry Lectureship: addressing the "core issue" in the design of estrogen receptor ligands, J Med Chem, 54 (2011) 5271-5282.

[9] M.E. Baker, Insights from the structure of estrogen receptor into the evolution of estrogens: implications for endocrine disruption, Biochem Pharmacol, 82 (2011) 1-8.

[10] L.J. Donoghue, T.I. Neufeld, Y. Li, Y. Arao, L.A. Coons, K.S. Korach, Differential Activation of a Mouse Estrogen Receptor beta Isoform (mERbeta2) with Endocrine-Disrupting Chemicals (EDCs), Environ Health Perspect, 125 (2017) 634-642.

[11] J.A. McLachlan, Environmental signaling: from environmental estrogens to endocrine-disrupting chemicals and beyond, Andrology, 4 (2016) 684-694.

[12] T.T. Schug, A.F. Johnson, L.S. Birnbaum, T. Colborn, L.J. Guillette, Jr., D.P. Crews, T. Collins, A.M. Soto, F.S. Vom Saal, J.A. McLachlan, C. Sonnenschein, J.J. Heindel, Minireview: Endocrine Disruptors: Past Lessons and Future Directions, Mol Endocrinol, 30 (2016) 833-847. [13] J.C. Nwachukwu, S. Srinivasan, N.E. Bruno, A.A. Parent, T.S. Hughes, J.A. Pollock, O. Gjyshi, V. Cavett, J. Nowak, R.D. Garcia-Ordonez, R. Houtman, P.R. Griffin, D.J. Kojetin, J.A. Katzenellenbogen, M.D. Conkright, K.W. Nettles, Resveratrol modulates the inflammatory response via an estrogen receptor-signal integration network, Elife, 3 (2014) e02057.

[14] M.E. Baker, Expanding the Structural Footprint of Xenoestrogens, Endocrine Disruptors, e967138 (2014). 
[15] G.V. Markov, J. Gutierrez-Mazariegos, D. Pitrat, I.M.L. Billas, F. Bonneton, D. Moras, J. Hasserodt, G. Lecointre, V. Laudet, Origin of an ancient hormone/receptor couple revealed by resurrection of an ancestral estrogen, Sci Adv, 3 (2017) e1601778.

[16] M.E. Baker, Recent insights into the origins of adrenal and sex steroid receptors, J Mol Endocrinol, 28 (2002) 149-152.

[17] G.N. Eick, J.W. Thornton, Evolution of steroid receptors from an estrogen-sensitive ancestral receptor, Mol Cell Endocrinol, 334 (2011) 31-38.

[18] J.W. Thornton, Evolution of vertebrate steroid receptors from an ancestral estrogen receptor by ligand exploitation and serial genome expansions, Proc Natl Acad Sci U S A, 98 (2001) 5671-5676. [19] J.T. Bridgham, J.E. Brown, A. Rodriguez-Mari, J.M. Catchen, J.W. Thornton, Evolution of a new function by degenerative mutation in cephalochordate steroid receptors, PLoS genetics, 4 (2008) e1000191.

[20] Y. Katsu, K. Kubokawa, H. Urushitani, T. Iguchi, Estrogen-dependent transactivation of amphioxus steroid hormone receptor via both estrogen and androgen response elements, Endocrinology, 151 (2010) 639-648.

[21] M. Paris, K. Pettersson, M. Schubert, S. Bertrand, I. Pongratz, H. Escriva, V. Laudet, An amphioxus orthologue of the estrogen receptor that does not bind estradiol: insights into estrogen receptor evolution, BMC evolutionary biology, 8 (2008) 219.

[22] H. Gao, K. Dahlman-Wright, The gene regulatory networks controlled by estrogens, Mol Cell Endocrinol, 334 (2011) 83-90.

[23] K.J. Hamilton, S.C. Hewitt, Y. Arao, K.S. Korach, Estrogen Hormone Biology, Curr Top Dev Biol, 125 (2017) 109-146.

[24] J.A. McLachlan, Environmental signaling: what embryos and evolution teach us about endocrine disrupting chemicals, Endocr Rev, 22 (2001) 319-341.

[25] P.S. Cooke, M.K. Nanjappa, C. Ko, G.S. Prins, R.A. Hess, Estrogens in Male Physiology, Physiological reviews, 97 (2017) 995-1043.

[26] G.S. Prins, K.S. Korach, The role of estrogens and estrogen receptors in normal prostate growth and disease, Steroids, 73 (2008) 233-244.

[27] G.G. Kuiper, B. Carlsson, K. Grandien, E. Enmark, J. Haggblad, S. Nilsson, J.A. Gustafsson, Comparison of the ligand binding specificity and transcript tissue distribution of estrogen receptors alpha and beta, Endocrinology, 138 (1997) 863-870.

[28] D.C. Leitman, S. Paruthiyil, O.I. Vivar, E.F. Saunier, C.B. Herber, I. Cohen, M. Tagliaferri, T.P. Speed, Regulation of specific target genes and biological responses by estrogen receptor subtype agonists, Curr Opin Pharmacol, 10 (2010) 629-636.

[29] F. Minutolo, M. Macchia, B.S. Katzenellenbogen, J.A. Katzenellenbogen, Estrogen receptor beta ligands: recent advances and biomedical applications, Med Res Rev, 31 (2011) 364-442. [30] N. Sugiyama, R.P. Barros, M. Warner, J.A. Gustafsson, ERbeta: recent understanding of estrogen signaling, Trends in endocrinology and metabolism: TEM, 21 (2010) 545-552.

[31] K.L. Zuloaga, D.T. O'Connor, R.J. Handa, R.J. Gonzales, Estrogen receptor beta dependent attenuation of cytokine-induced cyclooxygenase- 2 by androgens in human brain vascular smooth muscle cells and rat mesenteric arteries, Steroids, 77 (2012) 835-844.

[32] J.M. Arimoto, A. Wong, I. Rozovsky, S.W. Lin, T.E. Morgan, C.E. Finch, Age Increase of Estrogen Receptor-alpha (ERalpha) in Cortical Astrocytes Impairs Neurotrophic Support in Male and Female Rats, Endocrinology, 154 (2013) 2101-2113.

[33] V.L. Hedges, T.J. Ebner, R.L. Meisel, P.G. Mermelstein, The cerebellum as a target for estrogen action, Front Neuroendocrinol, 33 (2012) 403-411.

[34] A.M. Brzozowski, A.C. Pike, Z. Dauter, R.E. Hubbard, T. Bonn, O. Engstrom, L. Ohman, G.L. Greene, J.A. Gustafsson, M. Carlquist, Molecular basis of agonism and antagonism in the oestrogen receptor, Nature, 389 (1997) 753-758.

[35] S. Mocklinghoff, R. Rose, M. Carraz, A. Visser, C. Ottmann, L. Brunsveld, Synthesis and crystal structure of a phosphorylated estrogen receptor ligand binding domain, Chembiochem : a European journal of chemical biology, 11 (2010) 2251-2254. 
bioRxiv preprint doi: https://doi.org/10.1101/228064; this version posted December 4, 2017. The copyright holder for this preprint (which was not certified by peer review) is the author/funder, who has granted bioRxiv a license to display the preprint in perpetuity. It is made available under aCC-BY 4.0 International license.

[36] D.M. Tanenbaum, Y. Wang, S.P. Williams, P.B. Sigler, Crystallographic comparison of the estrogen and progesterone receptor's ligand binding domains, Proc Natl Acad Sci U S A, 95 (1998) 5998-6003.

[37] J.S. Sack, K.F. Kish, C. Wang, R.M. Attar, S.E. Kiefer, Y. An, G.Y. Wu, J.E. Scheffler, M.E. Salvati, S.R. Krystek, Jr., R. Weinmann, H.M. Einspahr, Crystallographic structures of the ligand-binding domains of the androgen receptor and its T877A mutant complexed with the natural agonist dihydrotestosterone, Proc Natl Acad Sci U S A, 98 (2001) 4904-4909.

[38] M.E. Baker, J.W. Funder, S.R. Kattoula, Evolution of hormone selectivity in glucocorticoid and mineralocorticoid receptors, J Steroid Biochem Mol Biol, 137 (2013) 57-70.

[39] A.K. Shiau, D. Barstad, P.M. Loria, L. Cheng, P.J. Kushner, D.A. Agard, G.L. Greene, The structural basis of estrogen receptor/coactivator recognition and the antagonism of this interaction by tamoxifen, Cell, 95 (1998) 927-937.

[40] Y. Li, C.J. Luh, K.A. Burns, Y. Arao, Z. Jiang, C.T. Teng, R.R. Tice, K.S. Korach, Endocrine-Disrupting Chemicals (EDCs): In Vitro Mechanism of Estrogenic Activation and Differential Effects on ER Target Genes, Environ Health Perspect, 121 (2013) 459-466.

[41] V. Delfosse, M. Grimaldi, J.L. Pons, A. Boulahtouf, A. le Maire, V. Cavailles, G. Labesse, W. Bourguet, P. Balaguer, Structural and mechanistic insights into bisphenols action provide guidelines for risk assessment and discovery of bisphenol A substitutes, Proc Natl Acad Sci U S A, 109 (2012) 14930-14935.

[42] G.G. Kuiper, J.G. Lemmen, B. Carlsson, J.C. Corton, S.H. Safe, P.T. van der Saag, B. van der Burg, J.A. Gustafsson, Interaction of estrogenic chemicals and phytoestrogens with estrogen receptor beta, Endocrinology, 139 (1998) 4252-4263.

[43] E.S. Manas, Z.B. Xu, R.J. Unwalla, W.S. Somers, Understanding the selectivity of genistein for human estrogen receptor-beta using X-ray crystallography and computational methods,

Structure, 12 (2004) 2197-2207.

[44] M.E. Baker, What are the physiological estrogens?, Steroids, 78 (2013) 337-340.

[45] E.R. Nelson, S.E. Wardell, J.S. Jasper, S. Park, S. Suchindran, M.K. Howe, N.J. Carver, R.V. Pillai, P.M. Sullivan, V. Sondhi, M. Umetani, J. Geradts, D.P. McDonnell, 27-Hydroxycholesterol links hypercholesterolemia and breast cancer pathophysiology, Science, 342 (2013) 1094-1098. [46] K. Saijo, J.G. Collier, A.C. Li, J.A. Katzenellenbogen, C.K. Glass, An ADIOL-ERbeta-CtBP transrepression pathway negatively regulates microglia-mediated inflammation, Cell, 145 (2011) 584-595.

[47] M. Umetani, H. Domoto, A.K. Gormley, I.S. Yuhanna, C.L. Cummins, N.B. Javitt, K.S. Korach, P.W. Shaul, D.J. Mangelsdorf, 27-Hydroxycholesterol is an endogenous SERM that inhibits the cardiovascular effects of estrogen, Nat Med, 13 (2007) 1185-1192.

[48] M. Garcia, H. Rochefort, Evidence and characterization of the binding of two 3H-labeled androgens to the estrogen receptor, Endocrinology, 104 (1979) 1797-1804.

[49] L.G. Van Doorn, J. Berenschot-Roozendaal, J. Poortman, J.H. Thijssen, F. Schwarz, Binding characteristics of 5-androstene-3 beta, 17 beta-diol and estradiol-17 beta to the cytoplasmic estrogen receptor of the immature rat uterus, J Steroid Biochem, 16 (1982) 661-671.

[50] J. Adams, M. Garcia, H. Rochefort, Estrogenic effects of physiological concentrations of 5-androstene- 3 beta, 17 beta-diol and its metabolism in MCF7 human breast cancer cells, Cancer research, 41 (1981) 4720-4726.

[51] D. Gosselin, S. Rivest, Estrogen receptor transrepresses brain inflammation, Cell, 145 (2011) 495-497.

[52] A. Gottfried-Blackmore, A. Sierra, P.H. Jellinck, B.S. McEwen, K. Bulloch, Brain microglia express steroid-converting enzymes in the mouse, J Steroid Biochem Mol Biol, 109 (2008) 96-107. [53] P.H. Jellinck, M. Kaufmann, A. Gottfried-Blackmore, B.S. McEwen, G. Jones, K. Bulloch, Selective conversion by microglia of dehydroepiandrosterone to 5-androstenediol-A steroid with inherent estrogenic properties, J Steroid Biochem Mol Biol, 107 (2007) 156-162.

[54] W.S. Griffin, Inflammation and neurodegenerative diseases, Am J Clin Nutr, 83 (2006) 470S-474S. 
[55] Y.S. Kim, T.H. Joh, Microglia, major player in the brain inflammation: their roles in the pathogenesis of Parkinson's disease, Exp Mol Med, 38 (2006) 333-347.

[56] C.K. Glass, K. Saijo, B. Winner, M.C. Marchetto, F.H. Gage, Mechanisms underlying inflammation in neurodegeneration, Cell, 140 (2010) 918-934.

[57] V.W. Yong, S. Rivest, Taking advantage of the systemic immune system to cure brain diseases, Neuron, 64 (2009) 55-60.

[58] G. Raivich, R. Banati, Brain microglia and blood-derived macrophages: molecular profiles and functional roles in multiple sclerosis and animal models of autoimmune demyelinating disease, Brain Res Brain Res Rev, 46 (2004) 261-281.

[59] S.M. Orton, B.M. Herrera, I.M. Yee, W. Valdar, S.V. Ramagopalan, A.D. Sadovnick, G.C. Ebers, Sex ratio of multiple sclerosis in Canada: a longitudinal study, Lancet Neurol, 5 (2006) 932-936.

[60] S.V. Ramagopalan, J.K. Byrnes, S.M. Orton, D.A. Dyment, C. Guimond, I.M. Yee, G.C. Ebers, A.D. Sadovnick, Sex ratio of multiple sclerosis and clinical phenotype, Eur J Neurol, 17 (2010) 634-637.

[61] Z. Weihua, R. Lathe, M. Warner, J.-A. Gustafsson, An endocrine pathway in the prostate, ERbeta, AR, 5alpha-androstane-3beta,17beta-diol, and CYP7B1, regulates prostate growth, Proceedings of the National Academy of Sciences of the United States of America, 99 (2002) 13589-13594.

[62] S. Muthusamy, S. Andersson, H.J. Kim, R. Butler, L. Waage, U. Bergerheim, J.A. Gustafsson, Estrogen receptor beta and 17beta-hydroxysteroid dehydrogenase type 6, a growth regulatory pathway that is lost in prostate cancer, Proc Natl Acad Sci U S A, 108 (2011) 20090-20094.

[63] K.L. Zuloaga, S.N. Swift, R.J. Gonzales, T.J. Wu, R.J. Handa, The androgen metabolite, 5alpha-androstane-3beta,17beta-diol, decreases cytokine-induced cyclooxygenase-2, vascular cell adhesion molecule-1 expression, and P-glycoprotein expression in male human brain microvascular endothelial cells, Endocrinology, 153 (2012) 5949-5960.

[64] B.L. Lasley, S. Crawford, D.S. McConnell, Adrenal androgens and the menopausal transition, Obstet Gynecol Clin North Am, 38 (2011) 467-475.

[65] B.L. Lasley, J. Chen, F.Z. Stanczyk, S.R. El Khoudary, N.A. Gee, S. Crawford, D.S.

McConnell, Androstenediol complements estrogenic bioactivity during the menopausal transition, Menopause, 19 (2012) 650-657.

[66] D.S. McConnell, F.Z. Stanczyk, M.R. Sowers, J.F. Randolph, Jr., B.L. Lasley, Menopausal transition stage-specific changes in circulating adrenal androgens, Menopause, 19 (2012) 658-663.

[67] C.D. DuSell, D.P. McDonnell, 27-Hydroxycholesterol: a potential endogenous regulator of estrogen receptor signaling, Trends Pharmacol Sci, 29 (2008) 510-514.

[68] C.D. DuSell, M. Umetani, P.W. Shaul, D.J. Mangelsdorf, D.P. McDonnell,

27-hydroxycholesterol is an endogenous selective estrogen receptor modulator, Mol Endocrinol, 22 (2008) 65-77.

[69] E.R. Nelson, C.D. DuSell, X. Wang, M.K. Howe, G. Evans, R.D. Michalek, M. Umetani, J.C. Rathmell, S. Khosla, D. Gesty-Palmer, D.P. McDonnell, The oxysterol, 27-hydroxycholesterol, links cholesterol metabolism to bone homeostasis through its actions on the estrogen and liver X receptors, Endocrinology, 152 (2011) 4691-4705.

[70] C.D. DuSell, E.R. Nelson, X. Wang, J. Abdo, U.I. Modder, M. Umetani, D. Gesty-Palmer, N.B. Javitt, S. Khosla, D.P. McDonnell, The endogenous selective estrogen receptor modulator 27-hydroxycholesterol is a negative regulator of bone homeostasis, Endocrinology, 151 (2010) 3675-3685.

[71] J.G. McDonald, D.D. Smith, A.R. Stiles, D.W. Russell, A comprehensive method for extraction and quantitative analysis of sterols and secosteroids from human plasma, J Lipid Res, 53 (2012) 1399-1409.

[72] J. Kaiser, Cancer. Cholesterol forges link between obesity and breast cancer, Science, 342 (2013) 1028. 
[73] Q. Wu, T. Ishikawa, R. Sirianni, H. Tang, J.G. McDonald, I.S. Yuhanna, B. Thompson, L. Girard, C. Mineo, R.A. Brekken, M. Umetani, D.M. Euhus, Y. Xie, P.W. Shaul, 27-Hydroxycholesterol Promotes Cell-Autonomous, ER-Positive Breast Cancer Growth, Cell Rep, 5 (2013) 637-645.

[74] G.V. Markov, V. Laudet, Origin and evolution of the ligand-binding ability of nuclear receptors, Mol Cell Endocrinol, 334 (2011) 21-30.

[75] K.W. Gaido, S.C. Maness, D.P. McDonnell, S.S. Dehal, D. Kupfer, S. Safe, Interaction of methoxychlor and related compounds with estrogen receptor alpha and beta, and androgen receptor: structure-activity studies, Mol Pharmacol, 58 (2000) 852-858.

[76] S.F. Arnold, M.K. Robinson, A.C. Notides, L.J. Guillette, Jr., J.A. McLachlan, A yeast estrogen screen for examining the relative exposure of cells to natural and xenoestrogens, Environ Health Perspect, 104 (1996) 544-548.

[77] J.C. Nwachukwu, S. Srinivasan, N.E. Bruno, J. Nowak, N.J. Wright, F. Minutolo, E.S. Rangarajan, T. Izard, X.Q. Yao, B.J. Grant, D.J. Kojetin, O. Elemento, J.A. Katzenellenbogen, K.W. Nettles, Systems Structural Biology Analysis of Ligand Effects on ER alpha Predicts Cellular Response to Environmental Estrogens and Anti-hormone Therapies, Cell Chem Biol, 24 (2017) 35-45.

[78] Dobzhansky.T, Nothing in Biology Makes Sense except in the Light of Evolution, American Biology Teacher, 35 (1973) 125-129.

[79] M.E. Baker, Evolution of adrenal and sex steroid action in vertebrates: a ligand-based mechanism for complexity, BioEssays : news and reviews in molecular, cellular and developmental biology, 25 (2003) 396-400.

[80] M.E. Baker, Origin and diversification of steroids: co-evolution of enzymes and nuclear receptors, Mol Cell Endocrinol, 334 (2011) 14-20.

[81] S. Bertrand, F.G. Brunet, H. Escriva, G. Parmentier, V. Laudet, M. Robinson-Rechavi, Evolutionary genomics of nuclear receptors: from twenty-five ancestral genes to derived endocrine systems, Molecular biology and evolution, 21 (2004) 1923-1937.

[82] M.E. Baker, Xenobiotics and the evolution of multicellular animals: emergence and diversification of ligand-activated transcription factors, Integr Comp Biol, 45 (2005) 172-178.

[83] M.E. Baker, Trichoplax, the simplest known animal, contains an estrogen-related receptor but no estrogen receptor: Implications for estrogen receptor evolution, Biochem Biophys Res Commun, 375 (2008) 623-627.

[84] J.T. Bridgham, G.N. Eick, C. Larroux, K. Deshpande, M.J. Harms, M.E. Gauthier, E.A. Ortlund, B.M. Degnan, J.W. Thornton, Protein evolution by molecular tinkering: diversification of the nuclear receptor superfamily from a ligand-dependent ancestor, PLoS Biol, 8 (2010).

[85] F.M. Sladek, What are nuclear receptor ligands?, Molecular and Cellular Endocrinology, 334 (2011) 3-13.

[86] S. Bertrand, M.R. Belgacem, H. Escriva, Nuclear hormone receptors in chordates, Mol Cell Endocrinol, 334 (2011) 67-75.

[87] M.E. Baker, Steroid receptor phylogeny and vertebrate origins, Mol Cell Endocrinol, 135 (1997) 101-107.

[88] H. Escriva, F. Delaunay, V. Laudet, Ligand binding and nuclear receptor evolution, BioEssays : news and reviews in molecular, cellular and developmental biology, 22 (2000) 717-727.

[89] G.V. Callard, A.M. Tarrant, A. Novillo, P. Yacci, L. Ciaccia, S. Vajda, G.Y. Chuang, D. Kozakov, S.R. Greytak, S. Sawyer, C. Hoover, K.A. Cotter, Evolutionary origins of the estrogen signaling system: insights from amphioxus, J Steroid Biochem Mol Biol, 127 (2011) 176-188. [90] T. Mizuta, K. Kubokawa, Presence of sex steroids and cytochrome P450 genes in amphioxus, Endocrinology, 148 (2007) 3554-3565.

[91] A.H. Gazzaley, N.G. Weiland, B.S. McEwen, J.H. Morrison, Differential regulation of NMDAR1 mRNA and protein by estradiol in the rat hippocampus, J Neurosci, 16 (1996) 6830-6838. 
[92] C.D. Toran-Allerand, The estrogen/neurotrophin connection during neural development: is co-localization of estrogen receptors with the neurotrophins and their receptors biologically relevant?, Dev Neurosci, 18 (1996) 36-48.

[93] C.S. Woolley, N.G. Weiland, B.S. McEwen, P.A. Schwartzkroin, Estradiol increases the sensitivity of hippocampal CA1 pyramidal cells to NMDA receptor-mediated synaptic input: correlation with dendritic spine density, J Neurosci, 17 (1997) 1848-1859.

[94] S.W. Mitra, E. Hoskin, J. Yudkovitz, L. Pear, H.A. Wilkinson, S. Hayashi, D.W. Pfaff, S. Ogawa, S.P. Rohrer, J.M. Schaeffer, B.S. McEwen, S.E. Alves, Immunolocalization of estrogen receptor beta in the mouse brain: comparison with estrogen receptor alpha, Endocrinology, 144 (2003) 2055-2067.

[95] X. Fan, M. Warner, J.A. Gustafsson, Estrogen receptor beta expression in the embryonic brain regulates development of calretinin-immunoreactive GABAergic interneurons, Proc Natl Acad Sci U S A, 103 (2006) 19338-19343.

[96] N. Sugiyama, S. Andersson, R. Lathe, X. Fan, P. Alonso-Magdalena, T. Schwend, I. Nalvarte, M. Warner, J.A. Gustafsson, Spatiotemporal dynamics of the expression of estrogen receptors in the postnatal mouse brain, Mol Psychiatry, 14 (2009) 223-232, 117.

[97] I. Bjorkhem, Five decades with oxysterols, Biochimie, 95 (2013) 448-454.

[98] C.N. Parkhurst, G. Yang, I. Ninan, J.N. Savas, J.R. Yates, 3rd, J.J. Lafaille, B.L. Hempstead, D.R. Littman, W.B. Gan, Microglia Promote Learning-Dependent Synapse Formation through Brain-Derived Neurotrophic Factor, Cell, 155 (2013) 1596-1609.

[99] J.R. Finnerty, Evolutionary developmental biology. Head start, Nature, 408 (2000) 778-779, 781.

[100] S.A. Green, M.E. Bronner, Gene duplications and the early evolution of neural crest development, Semin Cell Dev Biol, 24 (2013) 95-100.

[101] L.Z. Holland, Evolution of new characters after whole genome duplications: insights from amphioxus, Semin Cell Dev Biol, 24 (2013) 101-109.

[102] D.M. Medeiros, The evolution of the neural crest: new perspectives from lamprey and invertebrate neural crest-like cells, Wiley Interdiscip Rev Dev Biol, 2 (2013) 1-15.

[103] T.C. Lacalli, Basic features of the ancestral chordate brain: a protochordate perspective, Brain Res Bull, 75 (2008) 319-323.

[104] M.E. Baker, Y. Katsu, 30 YEARS OF THE MINERALOCORTICOID RECEPTOR:

Evolution of the mineralocorticoid receptor: sequence, structure and function, J Endocrinol, 234 (2017) T1-T16.

[105] G.V. Markov, R. Tavares, C. Dauphin-Villemant, B.A. Demeneix, M.E. Baker, V. Laudet, Independent elaboration of steroid hormone signaling pathways in metazoans, Proc Natl Acad Sci U S A, 106 (2009) 11913-11918.

[106] U.A. Hawkins, E.P. Gomez-Sanchez, C.M. Gomez-Sanchez, C.E. Gomez-Sanchez, The ubiquitous mineralocorticoid receptor: clinical implications, Curr Hypertens Rep, 14 (2012) 573-580.

[107] L. Martinerie, M. Munier, D. Le Menuet, G. Meduri, S. Viengchareun, M. Lombes, The mineralocorticoid signaling pathway throughout development: expression, regulation and pathophysiological implications, Biochimie, 95 (2013) 148-157.

[108] C.K. Wagner, The many faces of progesterone: a role in adult and developing male brain, Front Neuroendocrinol, 27 (2006) 340-359.

[109] T. Remer, K.R. Boye, M.F. Hartmann, S.A. Wudy, Urinary markers of adrenarche: reference values in healthy subjects, aged 3-18 years, J Clin Endocrinol Metab, 90 (2005) 2015-2021.

[110] T. Remer, F. Manz, M.F. Hartmann, E. Schoenau, S.A. Wudy, Prepubertal healthy children's urinary androstenediol predicts diaphyseal bone strength in late puberty, The Journal of clinical endocrinology and metabolism, 94 (2009) 575-578.

[111] R.J. Auchus, W.E. Rainey, Adrenarche - physiology, biochemistry and human disease, Clin Endocrinol (Oxf), 60 (2004) 288-296. 
[112] H. Ishimoto, R.B. Jaffe, Development and function of the human fetal adrenal cortex: a key component in the feto-placental unit, Endocr Rev, 32 (2011) 317-355.

[113] M.E. Baker, K.Y. Uh, C. Chandsawangbhuwana, 3D models of human ERalpha and ERbeta complexed with 5-androsten-3beta,17beta-diol, Steroids, 77 (2012) 1192-1197.

[114] L.N. Vandenberg, M.V. Maffini, C. Sonnenschein, B.S. Rubin, A.M. Soto, Bisphenol-A and the great divide: a review of controversies in the field of endocrine disruption, Endocr Rev, 30 (2009) 75-95.

[115] S. Yoshihara, T. Mizutare, M. Makishima, N. Suzuki, N. Fujimoto, K. Igarashi, S. Ohta, Potent estrogenic metabolites of bisphenol A and bisphenol B formed by rat liver S9 fraction: their structures and estrogenic potency, Toxicol Sci, 78 (2004) 50-59.

[116] M.E. Baker, C. Chandsawangbhuwana, 3D models of MBP, a biologically active metabolite of bisphenol A, in human estrogen receptor alpha and estrogen receptor beta, PloS one, 7 (2012) e46078.

[117] S. Eiler, M. Gangloff, S. Duclaud, D. Moras, M. Ruff, Overexpression, purification, and crystal structure of native ER alpha LBD, Protein Expr Purif, 22 (2001) 165-173. 